\title{
Benchmarking for Drinking Water Quality Assessment
}

\author{
Vladimir A. Grachev and Natalia I. Kurysheva
}

\begin{abstract}
The authors have developed a method for comparative analysis of water. This method involves water quality indicators benchmarking. The developed method presented in the paper differs from the method of simple harmonization of the maximum possible set of information involved in the field of comparison. Such an approach gives the possibility for comprehension and purposeful application of world experience in the qualitative performance of water supply A benchmarking algorithm has been developed for the "Vodokanal of St. Petersburg" enterprise and the efficiency of its use has been determined. As a result of the benchmarking implementation, all indicators of St. Petersburg water supply have been substantially improved.
\end{abstract}

Index Terms-Benchmarking, drinking water quality, water and sewage sector.

\section{INTRODUCTION}

The quality of drinking water is one of the most important factors of sanitary and epidemiological well-being of the population [1]-[5]. The health risk is a major factor in maintaining drinking water quality [6], [7]. To compare the quality, it is advisable to use the benchmarking method [8]-[16]. It is used in various fields from education to sales management and allows obtaining good results [17]-[20]. This paper discusses the way that benchmarking can be used for the water quality assessment. The authors analyze the origins of its use in Russia, its advantages over other methods of drinking water quality assessment, and its main characteristics. The authors conclude that benchmarking is an effective method for drinking water quality assessment.

In the water and sewage utilities sector, benchmarking is a method that was initially aimed to harmonize Russian regulations for drinking water quality assessment with those of other countries. Benchmarking is different from the simple harmonization method which stipulates that the best practices should be copied without any adjustments and allows to avoid copying practices and experience that would prove ineffective in the Russian setting. We believe that in order to work out the most suitable solutions, managers should take into account cause-and-effect relationship and the numerous (e.g. Regional) impact factors operating in the complex relational system of the water and sewage utilities sector. Benchmarking gives researchers and operators an opportunity to contemplate on the best foreign experience and assess in systematically. Thus, researchers and operators can gain insight into what is

Manuscript received February 28, 2019; revised August 12, 2019.

Vladimir A. Grachev is with the Global Ecology Center of Lomonosov Moscow State University, Moscow, Russia (e-mail: grachev@niipe.com).

Natalia I. Kurysheva is with the Burnasyan Federal Medical Biophysical Center of Federal Medical Biological Agency, Moscow, Russia (e-mail: e-natalia@list.ru). appropriate to implement and what prospects it would have in practice in the framework of factors affecting Russian water and sewage utilities sector.

How do we provide the population with good drinking water? How do we make water supply system sustainable so that economy and industry do not suffer from service water shortage? These questions have always been a priority for policymakers. Generally, Russia is fully supplied with water; however, the issue of water quality and ecologically and hygienically supported water supply remains essential.

Today, the Russian Federation is on the way to integration into the international community. One of the paths to it is to harmonize Russian legislation with that of the EU and other nations. On the one hand, this movement comes from external conditions of the market economy as well as from the wish to enter the WTO and to take an appropriate position in the international economic relations. On the other hand, Russia faces a complex set of issues associated with modernization of industry, structural modifications of economy, and implementation of innovative areas of economic growth that are intertwined with maintaining an environment in a favourable condition. To solve these issues, policymakers have to not only use internal reserves to the full but also attract larger foreign investment in the industry. However, foreign investment depends on the level of transparency of the Russian economy and on the lucidity of its legal platform, which guarantees reasonable profits and that invested money will be returned.

This paper aims to bring closer to each other Russian and international approaches to regulation on water supply and sewage systems. Another goal of this paper is to help eliminate barriers that hamper the water and sewage utilities sector from dynamic and innovative development in the Russian setting.

\section{METHODOLOGY}

Benchmarking is used as a tool for planning and managing economic and business activities. It allows economic entities and businesspersons to use unexplored opportunities and discover latent reserves that could help increase the entity's performance and gain competitive advantages.

Benchmarking is used as a tool for planning and managing economic and business activities. It allows economic entities and businesspersons to use unexplored opportunities and discover latent reserves that could help increase the entity's performance and gain competitive advantages.

First of all, benchmarking encompasses the following:

- A process of thorough measurement of a company's output by means of its comparison to that of the best enterprises and use of results of the comparison;

- A standard of dominance and achievement, regarding 
which the same values should be measured and analyzed;

- A systematic search for the best practices, innovative ideas, and new ways for the effective performance of processes that can lead to better output in the future;

- A process of definition, classification, and use of data as per the best corresponding practical examples. Such a process aims to improve any given business process by implementing the knowledge on more effective approaches, which gives way to better opportunities for gaining strategic, operational, and financial advantages.

Enterprises employ benchmarking to assess their prospect of success through a comprehensive study of activities of as many various (similar, alike, and different) successful companies as possible. Benchmarking is performed as part of competitive intelligence and is not novel to the vast majority of enterprises. Benchmarking is a more detailed and ordered function than the other methods and approaches used in the planning and management system.

In Fig. 1 below, you can see an algorithm that shows prospects of business performance improvement of a particular water and sewage utility.

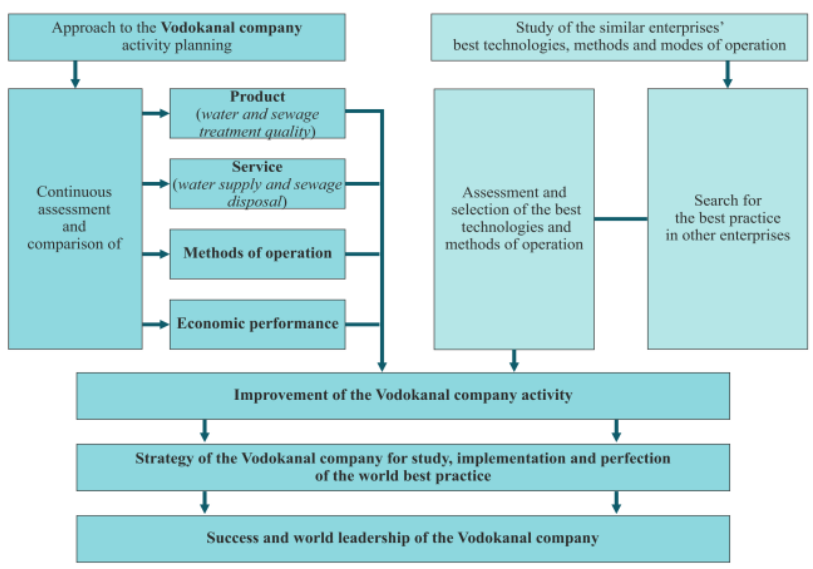

Fig. 1. Benchmarking scheme of the Vodokanal company.

The concept of benchmarking has a dominance analysis at the core. Dominance analysis is a complementary means for data acquisition that enterprises need to steadily increase production, its quality, and their competitiveness.

Dominance analysis is a particular perspective on internal functions and processes, relationships with partners as well as on other business activities. It is used to assess a company's gathered experience in order to define the best outcomes, analyze its activities, find flaws in functional processes, eliminate or strengthen weak spots, and create motivation for steady improvements.

When compared with other business tools, the advantages of benchmarking can be revealed by broad coverage of useful information that can be gathered from various sources and fields. In its turn, such information can be systematically analyzed and compiled into adequate and up-to-date data needed to make optimum decisions in different sectors, including the water and sewage utilities sector.

At the first glance, comparison of water supply and sewage utilities sector in developed countries, such as France, Germany, Sweden, Finland, the USA, Canada, Australia, etc., may be taken with a grain of salt, especially when there are internationally credible WHO guidelines and EU regulations.
However, such an analysis is necessary since it gives researchers insight into causes of differences in performance indicators that sometimes cannot be determined otherwise. A thorough analysis of a company's external factors, problems, and internal conditions that shape particularities of other similar enterprises helps assess business facts and estimate the company's uniqueness to gain advantages and increase competitiveness.

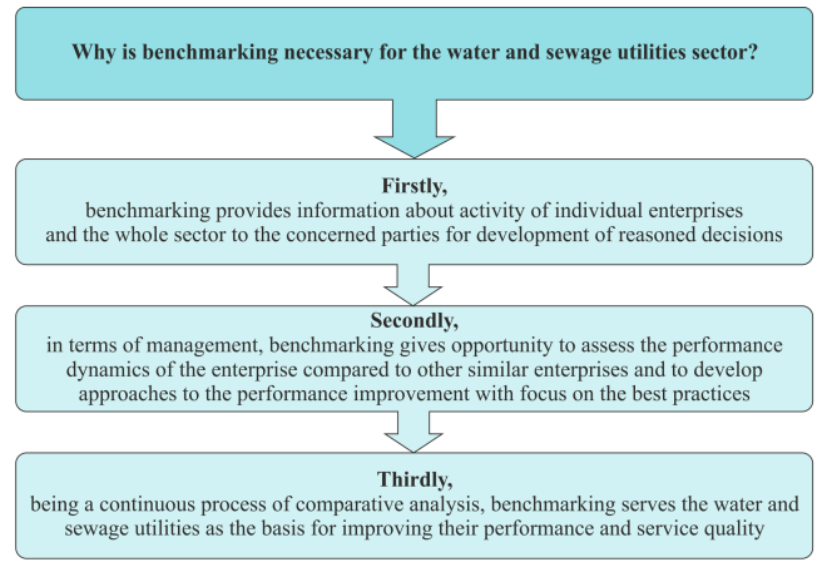

Fig. 2. Effects of the use of benchmarking in the water and sewage utilities sector.

In this context, benchmarking is a universal tool that allows decreasing expenses occurring in the period of adaptation to new harmonized principles of drinking water quality regulation and to changes in monitoring, control as well as to water treatment and delivery techniques and technologies associated with it. The same goes for the sewage system that is to be reformed in accordance with the energy preservation and efficiency legislation. Benchmarking is especially effective in drinking water quality assessment (Fig. 3).

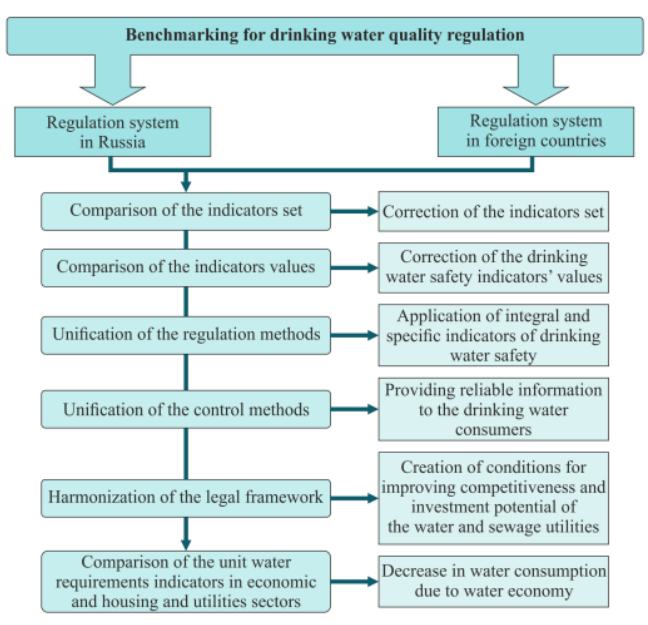

Fig. 3. Benchmarking for drinking water regulation.

\section{RESULTS}

The summarizing comparative analysis of the main indicators of the drinking water quality in foreign countries and Russia reveals the similarities and differences in the rationing systems of drinking water safety. It also allows determining the allowable composition and acceptable levels of quantitative values for each controlled indicator in the chronological aspect. This generally reflects trends in the 
field of regulation, in particular, the desire to optimize the composition and to establish justified quantitative values for priority substances.

Benchmarking of service and efficiency of the "Vodokanal of St. Petersburg," when correlated with the trends in the European rationing system, shows that the company holds a leading position among Russian organizations of water utilities and is not inferior to a significant part of European companies.

A generalized comparison of the regulatory indicators of a number of countries with actual indicators of water supply stations of the "Vodokanal of St. Petersburg" is given below. Based on the obtained data, the analysis of individual standards of drinking water quality was carried out. And their minimum and maximum values were interpreted taking into account Russian standards, standards of a number of foreign countries, and the WHO recommendations.

The results of the comparative analysis of the group of generalized physicochemical and organoleptic indicators are as follows:

- the pH value with the maximum range was determined in the Republic of South Africa 5.5-9.5; in Russia, this indicator is at the level of 6-9. At St.Petersburg's water supply stations, the average indicator is 6.58 ;

- water hardness in China is set at $450 \mathrm{mg} / \mathrm{l}\left(\mathrm{CaCO}_{3}\right)$, in Japan - $300 \mathrm{mg} / \mathrm{l}\left(\mathrm{CaCO}_{3}\right)$, in Russia - 7(10) meq/l. St. Petersburg's waterworks have an average level of 0.77 meq/l;

- the permanganate oxidizability index is the highest in France, Finland, and Russia, where its value is $5 \mathrm{mg} \mathrm{O}_{2} / 1$. At the St. Petersburg's waterworks, the average permanganate oxidizability is $3.26 \mathrm{mg} \mathrm{O}_{2} / 1$.

- in terms of odour, the maximum standards are observed in the Republic of South Africa - 5 points, and in the USA 3 points according to a 10-point rating system. In Russia, this indicator is at the level of no more than 2 points according to a 5-point scale. At the waterworks of St. Petersburg, the average value for the odour is 0 points;

- in terms of taste, in European countries, taste should be acceptable to the consumer or the absence of anomalies is required; in Russia, the "taste" norm is set at 2 points according to a 5-point rating system. At St. Petersburg's waterworks, the average taste value is 0 points.

- the water colour index at the maximum level is set in Sweden - 30 degrees. In the Republic of South Africa it is 20 degrees; the same is for Russia, specifying that 35 degrees can be set by the decision of the chief state sanitary doctor for the relevant territory for a specific water supply system, based on the assessment of the sanitary and epidemiological situation in the residential area and the water treatment technology applied. The level in France and China is lower - 15 degrees. At St. Petersburg's waterworks, the average colour index is 6.4 degrees;

- the turbidity at the maximum level is set in the Republic of South Africa, Brazil, and Australia - 5 NTU. In Russia, its value is at the level of 2.6(3.5) FTU in the distribution network. At waterworks in St. Petersburg, the average turbidity is 0.36 FTU.
The comparative analysis of microbiological and parasitological indicators has revealed that:

- for most countries, including Russia, a norm of E. coli absence is established, or E. coli presence should not be detected in $100 \mathrm{ml}$. The same requirements are applied to all coliform bacteria. At the St.Petersburg's water supply stations, the index is 0 ;

- the total microbial count is set at $100 \mathrm{CFU} / \mathrm{ml}$ in the Republic of South Africa, Germany, Japan, China. And in Russia, it is no more than $50 \mathrm{CFU} / \mathrm{ml}$. At water supply stations of St. Petersburg, the average value is 0.4 $\mathrm{CFU} / \mathrm{ml}$.

For the group of chemicals, including a subgroup of inorganic compounds, the following is noted:

- for aluminium, the maximum standard is in France, Japan, Brazil, China, Australia and Finland - $0.2 \mathrm{mg} / \mathrm{l}$; in Russia, the standard for aluminium is $0.5 \mathrm{mg} / \mathrm{l}$. In St. Petersburg, the value is $0.164 \mathrm{mg} / \mathrm{l}$;

- for barium, the maximum is in the USA - $2 \mathrm{mg} / \mathrm{l}$. In Germany, it is $1 \mathrm{mg} / \mathrm{l}$, in the Republic of South Africa $0.5(1) \mathrm{mg} / \mathrm{l}$. In Russia, the barium standard is $0.1 \mathrm{mg} / \mathrm{l}$. In St. Petersburg, the value is $0.016 \mathrm{mg} / \mathrm{l}$;

- for beryllium, the standard in the Republic of South Africa and China is set at $0.002 \mathrm{mg} / \mathrm{l}$; in Russia - 0.0002 $\mathrm{mg} / \mathrm{l}$. In St. Petersburg, the value is $0.00005 \mathrm{mg} / \mathrm{l}$;

- for boron, the maximum indicator is set in Canada - 5 $\mathrm{mg} / \mathrm{l}$. In Australia, it is $4 \mathrm{mg} / \mathrm{l}$, in France, Japan, Finland, Sweden and the EU Directive - $1 \mathrm{mg} / \mathrm{l}$. In Russia, the norm for boron is $0.5 \mathrm{mg} / \mathrm{l}$. In St. Petersburg, the indicator is $0.01 \mathrm{mg} / \mathrm{l}$;

- for cadmium, the maximum standard is set in Japan and the Republic of South Africa - $0.01 \mathrm{mg} / \mathrm{l}$. For France, Brazil, China, Finland, Sweden, the USA and Canada it is $0.005 \mathrm{mg} / \mathrm{l}$, in Germany - $0.001 \mathrm{mg} / \mathrm{l}$, in Russia - 0.001 $\mathrm{mg} / \mathrm{l}$. In St. Petersburg, the indicator is $0.00005 \mathrm{mg} / \mathrm{l}$;

- for arsenic, the maximum norm is in the Republic of South Africa - 0.1(0.3) mg/l. In France, Japan, Brazil, China, Finland, Sweden, the USA and Canada it is equal to $0.01 \mathrm{mg} / \mathrm{l}$. In Russia, the arsenic standard is $0.05 \mathrm{mg} / \mathrm{l}$. At waterworks in St. Petersburg, the arsenic average is $0.0025 \mathrm{mg} / \mathrm{l}$

- for nickel, the maximum value of the norm is established in the Republic of South Africa - 0.25(0.5) mg/l. In Germany its value is $0.05 \mathrm{mg} / \mathrm{l}$, in France, China, Australia, Finland and Sweden - $0.02 \mathrm{mg} / \mathrm{l}$; in Russia, nickel norm is set at the level of $0.1 \mathrm{mg} / \mathrm{l}$. At St. Petersburg's waterworks, the nickel value is $0.0008 \mathrm{mg} / \mathrm{l}$;

- for nitrates, the maximum value of the standard belongs to Germany, France, Finland, Sweden and Australia - 50 $\mathrm{mg} / \mathrm{l}$. In Russia, the nitrates norm is set at $45 \mathrm{mg} / \mathrm{l}$. At water supply stations of St. Petersburg, this value is 1.04 $\mathrm{mg} / \mathrm{l}$;

- for nitrites, the maximum standard is in Canada $-3.2 \mathrm{mg} / \mathrm{l}$. In Australia it is set at $3 \mathrm{mg} / \mathrm{l}$, in Finland and Sweden - 0.5 $\mathrm{mg} / \mathrm{l}$; in Russia, the standard is $3 \mathrm{mg} / \mathrm{l}$. At water stations of St. Petersburg, the value is $0.25 \mathrm{mg} / \mathrm{l}$;

- for mercury, the maximum standard is in Germany and the Republic of South Africa - $0.005 \mathrm{mg} / \mathrm{l}$. In the USA it equals $0.002 \mathrm{mg} / \mathrm{l}$, in France, Brazil, China, Australia, 
Canada, Finland and Sweden $-0.001 \mathrm{mg} / \mathrm{l}$. In Russia, the standard of mercury is $0.0005 \mathrm{mg} / \mathrm{l}$, with St. Petersburg's waterworks having $0.000005 \mathrm{mg} / \mathrm{l}$;

- for lead, the maximum norm is in the Republic of South Africa $-0.05(0.1) \mathrm{mg} / \mathrm{l}$. In the USA the norm is $0.015 \mathrm{mg} / \mathrm{l}$ in France, Germany, Japan, Brazil. China, Finland, Sweden, Australia and Canada $-0.01 \mathrm{mg} / \mathrm{l}$; in Russia, the norm for lead is set at a level of $0.03 \mathrm{mg} / \mathrm{l}$. The lead value at waterworks of St. Petersburg is $0.0011 \mathrm{mg} / \mathrm{l}$;

- for selenium, the standard in the USA is $0.05 \mathrm{mg} / \mathrm{l}$, in the Republic of South Africa - 0.02(0.05) mg/l, in Russia $0.01 \mathrm{mg} / \mathrm{l}$. At waterworks of St. Petersburg, the value is $0.0025 \mathrm{mg} / \mathrm{l}$;

- for silver, the maximum standard value in Australia and the USA is $0.1 \mathrm{mg} / \mathrm{l}$. In China it is $0.05 \mathrm{mg} / \mathrm{l}$, in Russia $0.05 \mathrm{mg} / \mathrm{l}$. The silver content at water stations in St. Petersburg is below the detection limit;

- for strontium, the maximum standard is established in Russia - $7 \mathrm{mg} / \mathrm{l}$. In the Republic of South Africa, the standard is equal to $2 \mathrm{mg} / \mathrm{l}$. Water supply stations of St. Petersburg have the value of $0.06 \mathrm{mg} / \mathrm{l}$;

- for antimony, the maximum value of the standard is set in the Republic of South Africa at the level of $0.05(0.1) \mathrm{mg} / \mathrm{l}$. The standard in Japan is $0.015 \mathrm{mg} / \mathrm{l}$, in Russia $-0.05 \mathrm{mg} / \mathrm{l}$. At the same time, WHO recommends setting a level of $0.02 \mathrm{mg} / \mathrm{l}$. At St. Petersburg waterworks, the content of antimony is below the detection limit;

- for uranium, the maximum standard is in the Republic of South Africa - 1(4) mg/l. In Japan and Australia, it is at the level of $0.002 \mathrm{mg} / \mathrm{l}$, in Russia - $0.015 \mathrm{mg} / \mathrm{l}$, which corresponds to the $\mathrm{WHO}$ recommendations. At water stations of St. Petersburg, the uranium content is below the detection limit;

- for fluorine, the maximum norm is established in the USA at the level of $4 \mathrm{mg} / \mathrm{l}$. In France, Finland, Brazil, Sweden, Australia, and Canada the value is $1.5 \mathrm{mg} / \mathrm{l}$; in Russia, the standard for fluorine, depending on the climatic zone, is in the range of $1.2-1.5 \mathrm{mg} / \mathrm{l}$. The EU Directive and WHO recommendations suggest a fluoride level of no more than $1.5 \mathrm{mg} / \mathrm{l}$. In St. Petersburg, the value is $0.15 \mathrm{mg} / \mathrm{l}$;

- for chromium, the maximum standard is set in Germany, the Republic of South Africa and the United States - 0.1 mg/l. In Finland, Sweden, France, Japan, Brazil, China, Australia, Canada and Russia, the chromium standard is $0.05 \mathrm{mg} / \mathrm{l}$, which is in line with the EU Directive and WHO recommendations. At the same time, the value at the water supply stations of St. Petersburg is at the level of $0.0005 \mathrm{mg} / \mathrm{l}$;

- for cyanides, the maximum standard belongs to Germany $-0.5 \mathrm{mg} / \mathrm{l}$. The value in the USA and Canada is $0.2 \mathrm{mg} / \mathrm{l}$; in Russia $-0.035 \mathrm{mg} / \mathrm{l}$, and in St. Petersburg the cyanides content is below the detection limit;

- for ammonium, the value of the standard in Brazil is 1.5 $\mathrm{mg} / \mathrm{l}$, the Republic of South Africa - 1(2) mg/l, Russia - 2 $\mathrm{mg} / \mathrm{l}$. In St. Petersburg, the indicator is $0.114 \mathrm{mg} / \mathrm{l}$;

- for bicarbonates, Russia established the maximum value of the standard - $400 \mathrm{mg} / \mathrm{l}$. In France, it is $100 \mathrm{mg} / \mathrm{l}$. The St. Petersburg's waterworks have no value for this indicator;

- for iron, the maximum value of the standard is set in the
Republic of South Africa and Russia - 0.3(1) mg/l. In Japan, Brazil, China, the USA, Canada, and Australia its level is $0.3 \mathrm{mg} / \mathrm{l}$. In St. Petersburg, the iron value is 0.03 $\mathrm{mg} / \mathrm{l}$;

- for copper, the maximum value of the norm belongs to Finland, Brazil and Sweden, and is set by the EU Directive - $2 \mathrm{mg} / \mathrm{l}$. In Japan, France, Australia, the USA, Canada, China and Russia the value is $1 \mathrm{mg} / \mathrm{l}$, in line with the WHO recommendations. The water supply stations in St. Petersburg demonstrate the value at the level of 0.0066 $\mathrm{mg} / \mathrm{l}$;

- for manganese, the standard value in Brazil, China, Australia and Russia is $0.1 \mathrm{mg} / \mathrm{l}$, which corresponds to the WHO recommendations. Finland, France, Japan, the Republic of South Africa, Sweden, USA and Canada established the standard at the level of $0.05 \mathrm{mg} / \mathrm{l}$. At waterworks in St. Petersburg, the indicator is $0.0048 \mathrm{mg} / \mathrm{l}$;

- for sulphates, Canada and Russia have the maximum values of the standard $-500 \mathrm{mg} / \mathrm{l}$. The permissible level set by the EU Directive is $250 \mathrm{mg} / \mathrm{l}$. St. Petersburg's waterworks have the value of $25.6 \mathrm{mg} / \mathrm{l}$;

- for chlorides, the maximum norm is established in Russia - $350 \mathrm{mg} / \mathrm{l}$, followed by the Republic of South Africa 250(600) mg/l. In Brazil, China, Finland, Australia, the USA and Canada it is also $250 \mathrm{mg} / \mathrm{l}$, that is as set by the EU Directive. At the same time, St. Petersburg's water stations demonstrate the value equal to $7.8 \mathrm{mg} / \mathrm{l}$;

- for chlorine dioxide, the maximum norm is established by the USA $-0.8 \mathrm{mg} / \mathrm{l}$. In Japan the parameter is equal to 0.6 $\mathrm{mg} / \mathrm{l}$, in Russia $-0.2 \mathrm{mg} / \mathrm{l}$. The WHO recommends a level of $0.7 \mathrm{mg} / \mathrm{l}$. The water stations of St. Petersburg have no such parameter.

For the group of chemicals, which includes a subgroup of organic compounds, the following can be stated:

- for benzo[a]pyrene, the maximum value of the standard belongs to Brazil - $0.0007 \mathrm{mg} / \mathrm{l}$. In Russia, benzo[a]pyrene norm is at the level of $0.000005 \mathrm{mg} / \mathrm{l}$. The WHO recommendation for this standard is $0.0007 \mathrm{mg} / \mathrm{l}$. At waterworks in St. Petersburg, the value is 0.0000005 $\mathrm{mg} / \mathrm{l}$;

- for benzene, the minimum of the norm is set in Finland, France, Sweden and Australia - $0.001 \mathrm{mg} / \mathrm{l}$. In China, Japan and Russia the value is set at $0.01 \mathrm{mg} / \mathrm{l}$. In St. Petersburg's waterworks, the benzene content is below the detection limit;

- for bromodichloromethane, the maximum standard is set in China - $1.36 \mathrm{mg} / \mathrm{l}$, while WHO recommends $0.06 \mathrm{mg} / \mathrm{l}$. In Russia, this parameter is established at the level of 0.03 $\mathrm{mg} / \mathrm{l}$, and in St. Petersburg, the parameter's level is $0.00078 \mathrm{mg} / \mathrm{l}$;

- for bromoform, the minimum norm is set in Japan - 0.09 $\mathrm{mg} / \mathrm{l}$. In Russia, the standard establishes the level of 0.1 $\mathrm{mg} / \mathrm{l}$, just as the WHO recommends. At water stations of St. Petersburg, the parameter is equal to $0.00005 \mathrm{mg} / \mathrm{l}$;

- for dibromochloromethane, in Japan, the indicator is regulated at the level of $1 \mathrm{mg} / \mathrm{l}$, in Russia, the standard is set at $0.03 \mathrm{mg} / \mathrm{l}$, and WHO recommends $0.1 \mathrm{mg} / \mathrm{l}$. In St. Petersburg, the value is $0.00005 \mathrm{mg} / \mathrm{l}$;

- for DDT, the minimum standard is in Australia - 0.00006 
$\mathrm{mg} / \mathrm{l}$. In Germany and China, the norm is $0.001 \mathrm{mg} / \mathrm{l}$, in Russia $-0.002 \mathrm{mg} / \mathrm{l}$. The waterworks of St. Petersburg declare the value of $0.00005 \mathrm{mg} / \mathrm{l}$;

- for dichloromethane, in Germany, the indicator is 0.6 $\mathrm{mg} / \mathrm{l}$, in Japan, Brazil and WHO recommendations -0.02 $\mathrm{mg} / \mathrm{l}$, in Canada $-0.05 \mathrm{mg} / \mathrm{l}$, in the USA $-0.005 \mathrm{mg} / \mathrm{l}$, and in Russia $-7.5 \mathrm{mg} / \mathrm{l}$. At waterworks of St. Petersburg, the value is $0.00005 \mathrm{mg} / \mathrm{l}$;

- for trichloroethylene, the minimum standard is set in Germany - $0.001 \mathrm{mg} / \mathrm{l}$. In Russia, the standard is established at a level of $0.005 \mathrm{mg} / \mathrm{l}$. WHO recommends $0.02 \mathrm{mg} / \mathrm{l}$. At waterworks of St. Petersburg, the parameter is equal to $0.0005 \mathrm{mg} / \mathrm{l}$;

- for formaldehyde, the maximum norm belongs to Australia $-0.5 \mathrm{mg} / \mathrm{l}$. In Russia, the standard is at the level of $0.05 \mathrm{mg} / \mathrm{l}$, while in St. Petersburg, the formaldehyde content is below the detection limit;

- for chloroform, the standard is $0.06 \mathrm{mg} / \mathrm{l}$ in China and Japan, in Russia - 0.2(0.06) mg/l. And at water supply stations of St. Petersburg, the indicator is $0.0108 \mathrm{mg} / \mathrm{l}$;

- for carbon tetrachloride, the maximum standard value is set in the USA and Canada $-0.005 \mathrm{mg} / \mathrm{l}$. In Russia it is $0.006(0.002) \mathrm{mg} / \mathrm{l}$. At waterworks in St. Petersburg, the value is $0.000082 \mathrm{mg} / \mathrm{l}$;

- for anionic surface-active substances (surfactants), in the USA, Brazil and Russia, the standard is set at a maximum level of $0.5 \mathrm{mg} / \mathrm{l}$. In Japan, it is $0.2 \mathrm{mg} / \mathrm{l}$. At the water stations in St. Petersburg, the indicator is at the limit of detection and is $0.013 \mathrm{mg} / \mathrm{l}$;

- for phenols, in Japan, the standard is set at $0.005 \mathrm{mg} / \mathrm{l}$; in China - $0.002 \mathrm{mg} / \mathrm{l}$, in Russia - $0.001 \mathrm{mg} / \mathrm{l}$. At water supply stations of St. Petersburg, the value is 0.00005 $\mathrm{mg} / \mathrm{l}$.

The comparison of the quality of water supplied by the St. Petersburg's water supply stations with foreign and Russian standards demonstrates the high quality of tap water in St. Petersburg according to microbiological indicators.

\section{CONCLUSION}

Positive consequences of the implementation of a water and sewage processing regulation system that we expect are as follows:

- Decrease in water consumption;

- Decrease in expenses occurring during water processing

- Decrease in sewage;

- Improvement of water bodies' condition;

- Quality water supply;

- Optimization of payments for wastewater discharge collected from clients of water and sewage utilities.

These advantages have a considerable influence on the water supply quality as a whole.

\section{CONFLICT OF INTEREST}

The authors declare no conflict of interest.

\section{AUTHOR CONTRIBUTIONS}

V.A. Grachev conducted the research and wrote the paper; N.I. Kurysheva analyzed the data; all authors had approved the final version.

\section{REFERENCES}

[1] G. V. Aydinov, "Modern hygienic technologies as a solution to regional problems associated with population health protection," Doctor of medicine dissertation, Moscow Medical Academy, Moscow, Russia, 1999.

[2] T. A. Maslakova, "Statistical modelling of interrelation between public health and environmental factors," Ph.D. dissertation, Mathematical Analysis Dept., Institute of Industrial Ecology UB RAS, Yekaterinburg, Russia, 2007.

[3] U.S. Environmental Protection Agency, Health Assessment Document for Chromium, U.S. Environmental Protection Agency-600/8-83-014F Final Report, North Carolina: EPA, 1984.

[4] U.S. Environmental Protection Agency, Health Assessment Document for Nickel and Nickel compounds, U.S. Environmental Protection Agency-600/8-83/012FF Final Report, North Carolina: EPA, 1986.

[5] U.S. Environmental Protection Agency, Updated Mutagenicity and Carcinogenicity of Cadmium, U.S. Environmental Protection Agency-600/8-83-025F, Springfield, VA: EPA, 1985.

[6] A. V. Kiselyov, A. P. Scherbo, and K. B. Fridman, "Organizational and methodological aspects of the implementation of risk assessment methodology in practical activities of public health services," Hygiene and Sanitation, vol. 6, pp. 81-82, June 2002.

[7] A. P. Scherbo, Environment and Health: Approaches to Assessing Risks, Saint-Petersburg: Russia North-western State Medical University, 2002, ch. 3.

[8] M. Skelton, The Continuing Value of Benchmarking, Houston, TX: APQC, 2003.

[9] J. R. Evans and W. M. Lindsay, The Management and Control of Quality, 5th ed., Ohio: South Western, 2002, ch. 10.

[10] H. Harrington and J Harrington, High Performance Benchmarking, 1st ed., New York: McGraw-Hill, 1995.

[11] D. Rigby, Management Tools 2003. An Executive's Guide, Boston, USA: Bain \& Company Inc., 2003.

[12] E. A. Mikhailova. (June 2003). Basics of benchmarking: Use of benchmarking methods and TQM in creative labour. Management in Russia and Abroad. [Online] Available: https://www.cfin.ru/press/management/2001-6/14.shtml

[13] R. C. Camp, Business Process Benchmarking: Finding and Implementing Best Practices, Singapore: Toppan, 1995.

[14] J. W. Alstete, Benchmarking in Higher Education, ASHE-ERIC Higher Education Report No.5., Washington D.C.: The George Washington University Graduate School of Education and Human Development, 1995.

[15] S. Tucker, Benchmarking: A Guide for Educators, Thousand Oaks, CA: Corwin Press, 1995.

[16] D. E Kempner, "The pilot years: The growth of the NACUBO benchmarking project," Business Officer, vol. 27, no. 6, 1993, pp. 21-31.

[17] K. R. McKinnon, S. H. Walker, and D. Davis, Benchmarking: A Manual for Australian Universities, Canberra: Dept. of Education, Training and Youth Affairs, Higher Education Division, 2000.

[18] Australian Vice-Chancellors' Committee, Academic Standards in Higher Education: Biochemistry, Report of the Academic Standards Panel, Canberra: AVCC, 1993.

[19] U. Swan, "International benchmarking and national quality assessment systems: The case of Sweden," The Journal of EAIR, Tertiary Education and Management, vol. 10, no. 3, 2004, pp.173-192.

[20] A. Karjalainen, K. Kuortti, and S. Niinikoski, Creative Benchmarking. Designing Sustainable International Cooperation in Higher Education, Oulu: University Press of Oulu, 2002.

Copyright $@ 2019$ by the authors. This is an open access article distributed under the Creative Commons Attribution License which permits unrestricted use, distribution, and reproduction in any medium, provided the original work is properly cited (CC BY 4.0).

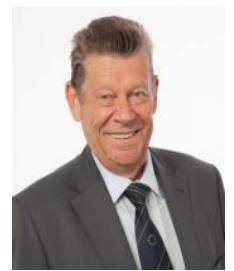

Vladimir A. Grachev was born in a small village of Taimanikha, Rodnikovsky District, Ivanovo Region, Russia, on March 2, 1942. In 1960, he graduated from the Ivanovo Industrial College, and in 1961 enrolled in the Penza Polytechnic Institute specializing in the foundry. In 1966, he graduated with honours. In 1967 , he enrolled in the graduate school of the Moscow State Institute of Electronics and Mathematics. In 1969 he 
defended his thesis in engineering and in 1987 his doctoral dissertation in the same field. Since 1991, he has been a corresponding member of the Russian Academy of Sciences in the department of physical chemistry and technology of inorganic materials. In 1996, he received a second degree in law at the Penza State University.

He started his career in the 1960s as an engineer at the Penza Compressor Plant; from 1974 to 1991 he was a lecturer and later held a chair at the Penza State Polytechnical Institute. In 1990, he was elected a People's Deputy, Deputy Chairman of the Committee on Higher Education and Training at the Supreme Council of the Russian Federation. In 1993-1999, he was the Chief of the Federation Council's Committee on Science, Culture, Education, Health and Ecology. In 1999-2007, he was elected a deputy of the State Duma, the Chairman of the Committee on Ecology. Since 2008, he has been the Adviser to the Director General of Rosatom, Moscow. He is also a member of the Parliamentary Assembly of the Council of Europe since 2000. $\mathrm{He}$ defends the interests of the Russian Federation on issues of ecology, environment, nuclear energy, science, education, agriculture, culture etc. Currently, he continues his work at the PACE as an expert of the Russian Federation delegation. He also currently occupies the position of the President of the V.I. Vernadsky Nongovernmental Ecological Foundation, Moscow

Dr. Grachev is the author of 243 inventions (369 patents), 730 published works, 29 monographs, 10 textbooks, 15 manuals.

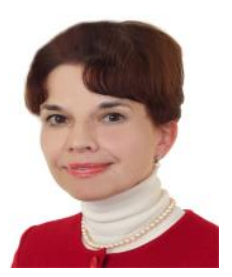

Natalia I. Kurysheva was born in the town of Ivanovo, Ivanovo Region, Russia, on December 10, 1962. In 1986, she graduated from Ivanovo State Medical Academy and applied for an internship at the Ophthalmology Department of the same university. In 1987, she finished the internship and enrolled for residency training at the same department. From 1990 to 1993 , she was taking up a full-time postgraduate study at the same department. In 2000, she applied for ophthalmology doctorate at the S.N. Fyodorov Eye Microsurgery Complex and received it in 2004.

She has 25 years of working experience as an eye surgeon and ophthalmologist. Today, Natalia Kurysheva occupies the position of Head of Ophthalmology Diagnostic Centre at Burnasyan Federal Medical Biophysical Center of Federal Medical Biological Agency in Moscow, Russia. She is also a professor at the Ophthalmology Department of the Federal Biomedical Agency Advanced Training School, in Moscow, Russia. Natalia Kurysheva is a member of the Russian Ophthalmology Society, the American Academy of Ophthalmology (since 2011), and the European Glaucoma Society.

Dr. Kurysheva is the author of 320 scientific papers, 8 methodological papers, 8 patents and inventions, and 7 monographs. 